\title{
USE OF INNOVATIVE TECHNOLOGIES IN TEACHING ORGANIC CHEMISTRY
}

\section{Saydaxmetova Shaxnoza Ravshanbekovna}

Senior Lecturer, Department of Chemistry and Teaching Methods, Tashkent State Pedagogical University named after Nizami Saydaxmetova_shaxnoza77@mail.ru

\begin{abstract}
The science of modern technologies in the teaching of organic chemistry prepares students for the methodological training of future chemistry. A chemistry teacher must have the knowledge, skills and competencies necessary to use modern pedagogical technologies in their pedagogical work. In order for students to use pedagogical technologies in the educational process, they must first be able to combine information and pedagogical technologies. This textbook provides an opportunity to organize the lesson in a combination of information technology and modern pedagogical technologies, to develop the knowledge, skills and abilities necessary for the use of modern pedagogical technologies in the teaching of chemistry.
\end{abstract}

\section{KEYWORDS:}

Organic chemistry, innovative technologies, concept, saturated hydrocarbons, individualization.

Article Received: 18 October 2020, Revised: 3 November 2020, Accepted: 24 December 2020

At present, when the teaching staff discusses the strategic directions of the development of general education and the formation of a new system in which the main characteristic is the formation of creative abilities of students, the effectiveness of the educational process is pedagogical technologies. It is impossible to imagine a modern learning process without looking for new, more effective technologies that contribute to the development of students 'creative abilities.

The content of the curriculum of higher education institutions in chemistry contributes greatly to the memorization of the material studied by the student, but it does not always develop creative intellectual activity. Throughout the entire learning process, the chemistry teacher faces the question of how to develop students 'creative abilities and form creative competencies? The search for a solution to this problem has led to the need to advance the hypothesis that "experimental technologies of chemistry teaching" have become the leading idea of the experiment.
Person-centered learning is the development of a student's personality, characteristics, and abilities, taking into account his or her thinking and action strategies. This involves adapting the learning environment to the student's abilities. According to him, the learning environment, pedagogical conditions, the whole process of education and upbringing means the realization of the student's personal potential, the development of abilities, the development of the individual, the enrichment of thinking and worldview. This type of education helps to develop in students such qualities as independence, initiative, responsibility, as well as the ability to think independently, creatively and critically.

Based on the theory of didactics, aimed at developing students' personalities and their creative self-understanding, the concept of combining innovative technologies is at the heart of teaching chemistry. The student becomes the subject of the learning process and becomes an active participant in it, and the teacher becomes the organizer of the student's cognitive activity. The answer found independently is a small victory of students in the study of the complex world of 
nature, a victory that gives confidence in his abilities, a victory that creates positive emotions, eliminates unconscious resistance to the learning process. Thus, the student asserts himself as an individual. Interest in the subject and most importantly, in the process of learning itself. Cognitive interest arises.

In connection with the personal formation of educational subjects, the development of students' abilities, the development of their knowledge, skills, methods of activity, competencies, chemistry teacher combines innovative technologies of the modern educational process. These include: problem-based learning technology, multi-level learning technology, game learning technology, information and communication technology, integrated learning technology, project technology, educational reflection of students.

The teacher, as an active subject of the educational process, sets goals: to increase the learning activity of students, to overcome fatigue and difficulties, to master the subject, to develop scientific interest, to apply the science of organic chemistry. I think it is necessary to increase the direction. The solution of the following tasks will help to achieve the goal:

Involve students in solving the set goals of the lesson, develop students' ability to manage the learning process together and self-manage;

increase interest and curiosity about the content of the material being studied;

The teacher uses a student-centered approach to solve the given tasks.

The student determines the direction of self-awareness on the basis of existing abilities, tendencies, interests and chooses the direction of education that is closest to him. Choosing a level of difficulty is very flexible and cannot be done "forever". The teacher prepares the students to choose the tasks independently, advises which task to choose, but the choice remains with the student. In higher education, the study of every subject is not a goal, but a means of child development. To assess student achievement, it is determined how the content is mastered: at the level of repetition of facts, their reconstruction, or at a variable level (at the level of mental operations).

Game learning technology helps to increase students 'interest in a variety of learning activities and learning activities. Play has been used since ancient times as a method of teaching, passing on the experience of older generations to younger people. Game technology is often used in chemistry teaching, lessons are held - games. For example, in the study of organic chemistry in educational institutions: "Saturated Hydrocarbons" competition, "Hydrocarbons" Detective University, "Spiritus phenol conquest" travel lesson. Game learning technology helps students constantly assimilate their knowledge on the topic.

Conducting integrated lessons allows students to use a variety of tasks to help them develop an interest in science when discussing a learning topic. Combined lessons will remain in students 'memory for a long time. Example: Organic chemistry: "Oxygenated organic substances" - chemistry, biology, ecology, "Nucleic acids" - chemistry, biology.

Students use three types of integrated courses:

lesson - learning new material;

lesson - generalization and consolidation of what is learned;

lesson - knowledge control.

Project method technologies

Among the innovative pedagogical tools and methods that ensure the individualization of specialized education, design has a special place as the main type of educational activity. The project (Latin projectus - advanced) involves the development of an idea, the search for an answer to a question in advance, a tentative search, the solution of the problem in different ways. The project method understands the main meaning and purpose of learning - it creates the conditions for collaboration in the research community and thus helps the student to become a talented student. 
In the practice of teaching organic chemistry, project activities are carried out through the following.

A course such as a course or practical lesson;

Extracurricular activities, meaningful work;

Scientific and practical activity of students, defense of theses;

The teacher uses the following projects:

In conclusion, the use of the above technologies in education makes chemistry lessons more effective, is one of the ways to develop students 'cognitive and creative interest in chemistry as a science, and also helps to activate students' mental activity, confirming the hypothesis of work experience. . Innovative technologies contribute to the effectiveness of teaching organic chemistry.

Two recent initiatives from the EU, namely the Bologna Process and the Lisbon Agenda are likely to have a major influence on European Higher Education. It seems unlikely that traditional teaching approaches, which supported the elitist system of the past, will promote the mobility, widened participation and culture of 'life-long learning' that will provide the foundations for a future knowledge-based economy. There is therefore a clear need to seek new approaches to support the changes which will inevitably occur. The European Chemistry Thematic Network (ECTN) is a network of some 160 university chemistry departments from throughout the EU as well as a number of National Chemical Societies (including the RSC) which provides a discussion forum for all aspects of higher education in chemistry. This handbook is a result of one of their working groups, who identified and collated good practice with respect to innovative methods in Higher Level Chemistry Education. It provides a comprehensive overview of innovations in university chemistry teaching from a broad European perspective. The generation of this book through a European Network, with major national chemical societies and a large number of chemistry departments as members make the book unique. The wide variety of scholars who have contributed to the book, make it interesting and invaluable reading for both new and experienced chemistry lecturers throughout the EU and beyond. The book is aimed at chemistry education at universities and other higher level institutions and at all academic staff and anyone interested in the teaching of chemistry at the tertiary level. Although newly appointed teaching staff are a clear target for the book, the innovative aspects of the topics covered are likely to prove interesting to all committed chemistry lecturers.

As the President of the Republic of Uzbekistan I.Karimov noted: "Today, international life and human development have entered such a stage that now it is not military power, but intellectual potential, intelligence, thought, advanced technologies that are crucial." Today's demand is that the education of the younger generation should meet the requirements of the development of creative forces, the innovations of science and technology. Junior specialists graduating from secondary special, vocational education institutions should be ready to master not only the existing techniques and technologies, but also the high technologies that will be created in the future in the short term. This is due to the fact that after the independence of our country, the rapidly developing automotive, mining, oil and gas, chemical and light industry enterprises are being launched, and the most advanced technologies are rapidly entering.

President of the Republic of Uzbekistan IA Karimov's book "Uzbekistan for a Great Future" states that "Uzbekistan is justifiably proud of its mineral wealth, and almost all the elements of the famous Mendeleev's periodic table are found here." The fact that education is one of the most developed countries in the world requires a great deal of research and skill on the part of educators to make the 21 st century a century of intelligence and knowledge. At the current stage of development of society, the education system 
faces great challenges. In our country, teachers have a great responsibility. The development of our country depends on the results of their selfless and good work.

A modern teacher must be a person who is mature in all respects, a master of his profession, has a modern way of working, is aware of new teaching methods, is constantly working on himself and strengthens his knowledge and skills. The work on providing the educational process with advanced pedagogical and information technologies has been identified as one of the priorities in the second and third stages of the implementation of the National Training Program. One of the ways to improve the content of education is to create the necessary conditions for the formation and development of educational and information resources for students, which are the most important means of independent learning.

The establishment of a modern education system is closely linked with the introduction of information technology in the educational process. This is especially true of new forms and means of teaching based on information and telecommunication technologies. These include elearning, which requires the active use of elearning tools. Therefore, today it is important not only to teach future teachers how to use readymade e-books, but also to teach them the methods, ways and means of creating new forms.

The scientific novelty of the research is reflected in the substantiation of the pedagogical expediency of the use of computers as a teaching tool in teaching the section "Periodic Law and Periodic Table" of chemical elements, namely: self-study of academic lyceum students creation of a special electronic manual for assessment using the control and test method; development of lesson plans on the section "Periodic law and periodic table" of chemical elements; Develop guidelines for activating learning using e-manuals.

Further improvement of continuing education is being carried out in our country and abroad. The use of information and communication technologies is seen as a force for the development of innovative approaches to the organization of teaching and the modernization of all educational processes. To date, not enough work has been done in Uzbek on the use of electronic manuals. Some electronic versions also have less animation and more text. The objects in the theme are often illustrated. Developing students' imagination is important in teaching chemistry.

\section{LIST OF REFERENCES:}

[1] Fayzullaeva DM, Ganieva MA, Nematov I. Collection of teaching technologies in theoretical and practical training / Met. From the series of innovative educational technologies in secondary special, vocational education - T .: TSU, 2013. - 137 p.

[2] Chemistry we know and do not know\| M.Primkulov, R.Ziyaev, B.Akbarov, U.Haydarov -Teacherodiy Publishing House Tashkent - 2011.

[3] The book of sharp minds. B.Akbarov, M.Primqulov. Tashkent -Uzbekistan\| -2015.

[4] Mirkomilov SH.M., Omonov X., Rakhmarullayev N.G. Chemistry teaching methods.

[5] T .: "Finance and Economics". 2013.

[6] M.Nishonov, Sh.Mamajonov, V.Xujaev. Methods of teaching chemistry. T-2002.

[7] Lutfullayev U. Laboratory classes on inorganic chemistry. T .: 2013.

[8] Mirziyoev Sh. M. A free and prosperous, democratic state of Uzbekistan

[9] together. To the post of the President of the Republic of Uzbekistan

[10] of the Chambers of the Oliy Majlis dedicated to the inauguration ceremony

[11] speech at the joint meeting / Sh.M. Mirziyoev. - Tashkent: Uzbekistan, 2016. - 56 p.

[12] Mirziyoev Sh M. Critical analysis, strict discipline and personal

[13] responsibility is the daily rule of every leader's activity 
[14] need Socio-economic development of our country in 2016

[15] the main results and the most important of the economic program for 2017

[16] expanded Cabinet of Ministers devoted to priorities

[17] report at the meeting, January 14, 2017 / Sh.M. Mirziyoev. - Tashkent:

[18] Uzbekistan, 2017. - 104 p.

[19] Mirziyoev Sh. M. The rule of law and the protection of human interests is the country

[20] development and guarantee of the well-being of the people. Republic of Uzbekistan

[21] Ceremony dedicated to the 24th anniversary of the adoption of the Constitution

[22] speech at the ceremony. December 7, 2016 /Sh.M.Mirziyoev. - Tashkent:

[23] "Uzbekistan", 2017. - 48 p.

[24] Mirziyoev Sh.M. Our great future with our brave and noble people

[25] we build together. From this book the President of the Republic of Uzbekistan Shavkat

[26] Mirziyoyev from November 1 to 24, 2016 with representatives of voters of the Republic of Karakalpakstan, regions and the city of Tashkent

[27] his speeches at pre-election rallies.

[28] /Sh.M.Mirziyoev. - Tashkent: "Uzbekistan", 2017. - 488 p.

[29] DECREE OF THE PRESIDENT OF THE REPUBLIC OF UZBEKISTAN.

[30] Actions for further development of the Republic of Uzbekistan

[31] about strategy. (Legislation of the Republic of Uzbekistan

[32] Collection, 2017, No. 6, Article 70)

[33] L.V.Golish "Active methods of teaching: content, selection, implementation». $\mathrm{T} \quad$. : Medium

[34] Center for Special Vocational Education, 2001.

[35] T.S.Nazarova, A.A.Grabetskiy, V.N.Lavrova. Experience in chemistry in school

[36] transfer T .: Teacher. $1992 \mathrm{y}$.
[37] 7.Improving the Methodology of Teaching the role of Metals in Biochemical Processes using Pedagogical Texnologies

[38] Bosma

[39] Engineering a Management TEST. Volume 83. May-June 2020. Page: 26638-26645

[40] 8 bet

[41] Sh.X.Shomurotova

Sh.B.Farmonova N.I.Kamalova

http://www.testmagzine.biz/index.php/testma gzine/issue/view/9

[42] www. tdpu.uz

[43] 12.www.pedagog.uz

[44] 13.www.Ziyonet.uz

[45] 14.www.edu.uz

[46] 15.tdpu-INTRANET.ped.

[47] 16. www.grain. $\mathrm{Ru}$

[48] 17. www.plant protection.com.

[49] 18. www.chemistry.r 